\title{
Poetic Industry: The Modernity of the Rhyming Weavers
}

\section{Charles I. Armstrong}

There has been a glut of recent Irish literature engaging, in a rich and diverse way, with the legacy and form of textiles. ${ }^{1}$ This recent efflorescence of activity might easily lead us to overlook an older and frequently neglected strand of literature crossing the borders between the textile and the textual. The eighteenth and nineteenth-century Ulster-Scots labouring poets, collectively identified as the Rhyming Weavers, constitute a singular chapter in the history of such interdisciplinary activity in Ireland. This group of writers built on the precedent of Robert Burns and earlier Scottish eighteenth-century poets to develop an individual poetry of their own, which was often (but far from always) based on Ulster-Scots dialect. This paper will investigate the singular dimension the combination of the vocations of writer and weaver give their writings, elucidating how poems by James Orr, Thomas Beggs, and David Herbison engage with modernity through the mechanization of the textile industry.

John Hewitt's Rhyming Weavers \& Other Country Poets of Antrim and Down, published in 1974, is a foundational work in the modern appreciation of the Rhyming Weavers. Hewitt's book not only contains a judicious selection of texts from the period, but also has a lengthy introduction that defines the field. It was based on his MA thesis, entitled Ulster Poets, 18001870 , and integrates previously published work going back to the 1940s. One can presume that Hewitt's scholarly work on this poetry has been an important influence on major Irish poems dealing with textiles over the last few decades; particularly Ciaran Carson and Michael Longley must be presumed to have known of it, and Tom Paulin's foreword to the 2004 reissue of Rhyming Weavers describes himself as reading it 'with keen attention when it came out'.2 For the purposes of this essay, however, its importance is primarily as a key framing of the Rhyming Weavers as a distinct historical phenomenon. As the title of his study indicates, Hewitt isolates the achievements of a group of poets largely based in the north-east of Ireland. His Rhyming Weaver has a distinctly regional identity, mainly communicating with his local community through producing a poetry of everyday life, but also engaging a broader, regional network through subscriptions. The frequent use of dialect verse is a linguistic trait that underlines the rootedness of Hewitt's ideal figure. There is a nostalgic, Marxist dimension to Hewitt's interpretation that is of paramount importance. For him, the Weavers present an accomplishment that strongly contrasts with the later alienation accompanying the industrial revolution:

So when we think of the rural bard's integration with his community, it is to be remembered that community itself was altogether more organic and self-contained, not ironed flat by standardization of education, of the instruments of opinion, not drained by railways and improved roads into, or infected with, a proletarianized urban complex. The hand-loom in the

\footnotetext{
${ }^{1}$ This is particularly evident in the work of poets such as Sinéad Morrissey, Michael Longley, Seamus Heaney, and Ciaran Carson, to name but a few. For an enlightening interpretation of the important of textiles and textile metaphors in Carson's poetry, see Jenny Malmqvist, Belfast Textiles: On Ciaran Carson's Poetics (Linköping: Linköping University, 2013).

${ }^{2}$ Tom Paulin, 'Foreword', Rhyming Weavers \& Other Country Poets of Antrim and Down, ed. John Hewitt (Belfast: The Blackstaff Press, 2004 [1974]), vii.
} 
house, the village, the reading room or the Masonic lodge at the crossroads for a brief period offered a unique equilibrium for the emergence of some remarkable talents. ${ }^{3}$

This pastoral ideal of complete embodiment and total harmonization with the human environment effectively limits the high-point of the Weavers' activity to a brief period around the turn from the eighteenth to the nineteenth century. As early a figure as Thomas Beggs, who started publishing in the late 1820s, is reduced by historical circumstances (as well as his employment in a bleachworks) to being a marginal figure: 'Beggs had nothing of the rooted, local quality of the other rural bards'. ${ }^{4}$ To be sure, there is no doubt that the textile industry underwent a dramatic change in this period. Gearóid Ó Tuathaigh notes, for instance, that the cotton industry 'faced a succession of crises in the early 1820 s from which it never recovered'. ${ }^{5}$ These crises included a drop in prices after the end of Napoleonic Wars, the abolition of protective tariffs, and new competition from linen. The supremacy of linen was facilitated by the construction of profitable, large-scale factories. But does such a shift in the industry necessarily entail an attenuation of literary creativity? In addition to creating a rather exclusionary historical narrative, Hewitt's localized, rural understanding of the Rhyming Weaver effectively also entails reducing the literary texts of these writers to simple (if idealized) objects of communication and exchange, devoid of the complexities and openendedness characteristic of a more modern work of art.

Although no one denies its central place in the defining, and making accessible, the Rhyming Weavers, more recent criticism has questioned some of the foundations of Hewitt's work. Ivan Herbison, for instance, has contested Hewitt's overly narrow definition of the Weavers in terms of gender, place, and religious affiliation. ${ }^{6}$ In the current critical context, the relatively constrictive confines of the latter's understanding of these Ulster-Scots poets seems exclusionary, and it seems justified to open up the canon along the same lines as have occurred for other periods and movements of literary history. According to Herbison, such an approach is required in order to rescue these writers from obscurity. One might however question whether mere diversification will facilitate greater critical prominence and appreciation. In any case, this essay will try to home in on one particular - and indeed rather narrow - defining trait of the Rhyming Weavers: the fact that some (but far from all) of them were, as is indeed suggested by the moniker, both poets and weavers.

What, for these writers, defines the relationship between rhyming and weaving? I want to propose that the confrontation, in this verse, with threats to weaving as a profitable, rural occupation can be understood productively, not as a simple marker of a fall from prelapsarian harmony but as a crucial feature that the Rhyming Weavers engaged with in a critical manner. These threats are manifold, and solicit different responses, none of which entail a simply dismissive relationship to modernity. It is only through a sense of real or suggested breakdown, and threat to the vocation of weaving, that the full force of these poets' creative resources is revealed. This is in some respects a typically Romantic scenario, and can be compared with the narrative Geoffrey Hartman identified in William Wordsworth: for Hartman, it is only in the default or errancy of nature - when nature lets the poet down - that Wordsworth discovers

\footnotetext{
${ }^{3}$ John Hewitt, ed., Rhyming Weavers \& Other Country Poets of Antrim and Down (Belfast: The Blackstaff Press, 2004 [1974]), 52.

${ }^{4}$ Hewitt, 109.

${ }^{5}$ Gearóid Ó Tuathaigh, Ireland Before the Famine, 1798-1848 (Dublin: Gill \& Macmillan, 2007 [1972]), 111.

'Ivan Herbison, 'Beyond the Rhyming Weavers', Études irlandaises 38.2 (2013): 41-54.
} 
the gift of his own imagination. ${ }^{7}$ In a somewhat similar fashion the breakdown or unravelling of weaving provides a productive impetus for the three Weaver poets interpreted in this article.

I also want to scrutinize the use of localities in these writings, in a way that does not simply pit rural belonging against urban deracination. There is more to be said about the role of place for the Rhyming Weavers, than to delineate the deleterious consequences of a move from the domestic handloom to the factory. Contrary to Hewitt's understanding of them, the Weavers already evince a creative tension in their handling of the differing exigencies of the poet's and the weaver's craft, and implicitly the poetic impulse can be seen to ally itself with the very forces of modernity that threaten the cottage industry. When this occurs, poetry gives access to a sense of deterritorialization or freedom from confinement, which exists in a form of dialectical tension with domestic belonging.

In 'The Work of Art in the Age of Mechanical Reproduction', Walter Benjamin observes that even 'the most perfect reproduction of a work of art is lacking in one element: its presence in time and space, its unique existence at the place where it happens to be'. ${ }^{8}$ The presence that is lost in reproduction is associated with authenticity, with the ritual nature of the aura, and is bound to a specific location. Effectively, what Hewitt identifies as the distinctive of the Rhyming Weavers is a specifically collective vision of such a pre-reproductive form of belonging: 'a poet of the folk was emphatically a poet of a place'. .9 In this context, the factory and the automatized processes of manufacturing embody the forces that Benjamin collected under the concept of 'mechanical reproduction'. When Carol Baraniuk finds fault with Hewitt for deradicalizing a poet such as James Orr, and reducing his poems referring to the 1798 uprising to 'vivid evocations of Orr's unhappy personal experience', ${ }^{10}$ we can thus link this to Benjamin's claim that a solely ritual understanding of art empties it of political potential. The Rhyming Weavers are not interesting despite their intense focus on the processes of industrialization: rather, this theme is key to their context and meaning. Yet, at the same time, this political dimension does not override, or exclude, a specifically aesthetic aspect to their work. By observing the estrangement of the textile process of production, these poets also bring to light a modern sense of the quasi-autonomy of the textual. Poetry, one might say, becomes an industry of its own.

'The Penitent', a poem by James Orr (1770-1816) written in 1800, offers us a first look at how a threat to weaving challenges the resources of the Rhyming Weaver. A narrative poem containing twenty stanzas of nine lines each, written in the Ulster-Scots dialect, 'The Penitent' tells the tale of the weaver Christy Blair. The third stanza proffers us a first, idyllic look at how Christy and his family are engaged in a domestic team effort:

He weav'd himsel', an' keept twathree gaun

Who prais'd him ay for hale weel-handled yarn;

His thrifty wife an' wise wee lasses span,

While warps and queels employ'd another bairn;

Some stript ilk morn an' thresh'd, the time to earn

To scamper wi' the houn's frae hill to hill;

\footnotetext{
${ }^{7}$ See especially Chapter 2, entitled 'The Via Naturaliter Negativa', in Geoffrey J. Hartman, Wordsworth's Poetry, 1787-1814 (New Haven: Yale University Press), 1971.

${ }^{8}$ Walter Benjamin, Illuminations, ed. Hannah Arendt, trans. Harry Zohn (New York: Schocken Books, 1968$), 220$.

${ }^{9}$ Hewitt, 33.

${ }^{10}$ Carol Baraniuk, James Orr, Poet and Irish Radical (London: Pickering \& Chatto, 2014), 11.
} 
Some learn'd the question-beuk in nyb'ring barn -

Christy wrought unco close, whyles took a gill,

But when his wab was out had ay a hearty fill. (II. 19-27) ${ }^{11}$

In these lines, Orr presents a summary of the domestic set-up of a family cottage industry of the eighteenth century. The gender division between spinning (female) and weaving (male) is typical for this period, while the distinctions between the different stages and elements of the process also underline the organized nature of the work. Blair is here presented as a relatively successful weaver, who is able to provide for his family and consistently delivers yarn to two or three ('twathree') customers. His whole family contributes to the family enterprise combining spinning and weaving - with a distribution of roles that leaves the children time both to work and play. Similarly, Christy's circumstances and routine allow him to enjoy leisure time. All this unfolds in an articulated, but closely-knit, spatial network of home, hill, and 'nyb'ring barn'.

If the family unit is a productive collective, the emphasis on leisure also signals that the discipline of modernity has not been fully internalized. The alcohol Christy enjoys in his spare time turns out to be the seed that sows his downfall. Soon his married bliss is a thing of the past, and his children too are neglected. The cantankerous noise he makes with his drinking friends replaces the sound of enterprise: 'He seldom car'd / To wake the looms mair profitable voice' (II. 57-58). What halts the dissipation, when Christy is brought 'to the frightfu' edge / O' dreary ruin' (II. 73-74), is a timely conversion. An itinerant Methodist preacher, speaking at a nearby barn, convinces him that he should 'join the flock / $A n^{\prime}$ imitate their lives wham ance he us'd to mock' (II. 80-81). As commentators have noted, Orr generally shows little interest in the specifics of the Methodist faith. Carol Baraniuk has suggested that the poem is an attempt to engage Orr's local Presbyterian minister, Reverend Bankhead (who is the dedicatee of the poem), in a theological debate. ${ }^{12}$ Yet although his protagonist is now said to pursue a 'heav'nward way' (I. 109), his life is less turned around by Wesleyan doctrine than the embrace of a meticulous, inner discipline. As Jane Gray has shown, a modern work ethic lies at the heart of the poem's vision. ${ }^{13}$ The disturbed ecosystem of his domestic relations is not merely restored to an even keel, rather it attains a new level of industry and harmony: 'sloth leas his hame; / He has baith kye an' corn, an' sells some meal, / His frien's outbye add mister till his name' (II. 114-116). The outcome of Christy's progress from harmony to dissipation, and then back to a heightened sense of prosperity and order, is intended to show a beneficent development in comparison with the modest industriousness of his initial family set-up:

They min't baith warls. In warps boil'd by their han'
Did thrice ten shuttles lose their entrails sma';
An' on a scoup o' cheap, but mountain lan',
They graz'd yell kye, an' drain'd an lim'd the shaw.
Beasts, yarn, an' claith, aft call'd the sons awa':
The daughters wash'd, and sew'd, an' span wi' care:
Christy did little, but directed a' (II. 154-160)

\footnotetext{
${ }^{11}$ All quotations from this poem are taken from James Orr, Poems on Various Subjects (Belfast: Smyth \& Lyons, 1804).

${ }^{12}$ Baraniuk, 159.

${ }^{13}$ Jane Gray, 'Folk Poetry and Working Class Identity in Ulster: An Anlysis of James Orr's "The Penitent", Journal of Historical Sociology 6.3 (September 1993): 249-275.
} 
The spatial delimitations of the family have expanded considerably, as their new economic clout moves beyond the home, also embracing the "mountain lan" and more distant markets. They have mastered to perfection the combination of farming and textile work that was quite frequent in Ulster during this period. ${ }^{14}$ The many active verbs in the middle section of this passage communicate a buzzing, ceaseless state of activity. Yet on the other hand, Christy himself has withdrawn from the field of action, moving from manual worker to manager. Earlier in the poem he was depicted as being subject to the physical demands of labour: 'Late, late did he sit up, an' early rise, / An eat the bread o' care to get it weav'd' (II. 105-6). Now, however, he has been liberated from the most pressing material exigencies. With this withdrawal also comes a disengagement from space: as the manager of this enterprise, Christy's place is everywhere and nowhere. If the reawakened loom has a 'mair profitable voice,' its amplification here is accompanied by a noticeable access of expansive freedom. In a rather mercantile fashion, Orr is here anticipating 'the truly desirable condition', which Seamus Heaney has described as linked to an innate capacity of poetry, 'of being king of infinite space'. ${ }^{15}$ The previous stanza of 'The Penitent' listed poets Young, Milton, and Gray alongside Biblical figures, hinting that the protagonist's transcendence is intimately linked with the imaginative mobility of literature. Tacitly, Christy has become an allegorical representation of the poet, growing out of but also transcending the specificity of place.

Orr's poem gives an optimistic view of the modernization of Ulster weaving. In a changing industry, his protagonist is an example of successful adaptation. Interestingly, his poem postdates Wordsworth's The Ruined Cottage (1797) by only three years. As Alan Liu has shown, Wordsworth's dark narrative details the deterioration of weaving in the north of England during the same period: the character of Robert in his poem is an emblem of ' $a$ distortion of the whole system' of local weaving, whereby largely independent households lost their economic footing. ${ }^{16} \mathrm{~A}$ similarly somber perspective can be found in many of the later poems of the Rhyming Weavers. Hewitt describes the development as coming through a tussle between 'two distinct cultures, the Victorian urban colliding ignorantly with the rural traditional'. ${ }^{17}$

In the poem 'The Auld Wife's Address to Her Spinning Wheel,' Thomas Beggs (17891847) addresses the defeat of the domestic industry by industrial mechanization. ${ }^{18}$ The speaker reminisces about her untroubled past, when by the fireside, 'My wee bit lamp hung laigh in the lum; / An' I sung my sang, an' my wheel I plied' (II. 6-7). Like Christy Blair's wife and daughters in 'The Penitent', she is a female character exclusively devoted to spinning rather than the more prestigious work of weaving. The poem takes place at a point when the 'hartsome hum' of her spinning wheel has ceased (I. 8), and she is now engaged in working through the industrial trauma of displacement and loss. ${ }^{19}$ The poem itself must however be understood as a song, with a 'hum' of its own, that risks embodying a repetitive acting out of the superfluity of the wheel. Like a wheel, the rhymes of the poem create a circular motion of

\footnotetext{
${ }^{14}$ Although typically based on farms, the most prosperous linen weavers were however not overly reliant on their own crops. See W. H. Crawford, The Handloom Weavers and the Ulster Linen Industry (Belfast: Ulster Historical Foundation, 1994), 24.

${ }^{15}$ Seamus Heaney, Finders Keepers: Selected Prose, 1971-2001 (London: Faber and Faber, 2002), 48.

${ }^{16}$ Alan Liu, Wordsworth: The Sense of History (Stanford: Stanford University Press, 1989), 331.

${ }^{17}$ Hewitt, 83.

${ }^{18}$ The full poem is printed in Crawford, 82-84.

${ }^{19}$ On the close connection between modernity, industrialization and the origin of our modern concept of trauma, see Chapter 1 of Roger Luckhurst, The Trauma Question (Manchester: Routledge, 2008).
} 
departure and return, the word 'wheel' itself filling the first rhyming position in the three first stanzas, before being replaced by the parodic 'squeal' in the same position in stanza four.

In the present of the old wife's lament, the 'machine' or 'ingine' of the factory has long since made her old instrument superfluous: 'men o' cunning 'an pelf, an' pride, / Hae made thee a useless thing to me' (II. 15-16). As 'wheel' passes over into 'squeal', its measured, harmonious sound is replaced by the cacophony of the factory workers:

$A n^{\prime}$ when they speak, it maun be wi a squeal;

They maun rise an' rin at the toll o' the bell,

An' brook the insult o' the tyrant an' de'il.

$A n^{\prime}$ the jargon they hear is the language o' hell. (II. 31-34)

As the redemption of Christy Blair was given a religious interpretation, the central contrast here between domestic and mechanized labour is filtered through a religious contrast between innocent purity and infernality. Beggs' poem dwells upon the moral degradation that awaits the typical female factory worker in 'a hot-bed rank wi' vice an' disease' (I. 30). The latter is 'sic a vile place' (I. 35), and replaces the open-ended freedom of the rural home ground with an exorbitant discipline of enclosure: 'Instead o' her ain father's cot on the green, / It puts the puir thing in a pitiful case' (II. 36-37). There is a faint pun in that last word, as the woman's constricted working environment is imbricated in her also being pigeonholed as a symptomatic figure, representative of modern degradation.

The 'new ingine' (I. 55) of automated labour has rendered the old companion, the spinning heel, 'a useless thing to me' (I. 16). This 'useless thing' resonates with the previously mentioned 'puir thing in a pitiful case' (as well as the self-reflective 'a thing like me' in the final stanza): Beggs is anticipating a Marxist analysis of objectification and loss of use value in the capitalist marketplace, and at a surface level his poem represents a scathing attack on the 'lords o' the Mill and Machine' that profit on the new urban, industrial complexes (II. 69-70). Yet although the anti-modern tenor of 'The Auld Wife's Address to the Spinning Wheel' is unmistakable, the poem displays a mastery and compensatory logic of its own: the poem itself comes into being through its replacing of the absent spinning wheel, even as the latter survives its own extinction through being preserved in song. There is a latent irony in the fact that the 'useless thing' is also the addressee of the poem: even if the Old Wife's late husband, Rorie, is mentioned in the poem, it is her 'cantie wee wheel' (I. 11) that most obviously engages her sentimentally and is the main object of her lament. 'In age an' youth', she declares, the wheel has been 'my staff an' my stay' (I. 12). The 'thing' that has been taken out of the realm of the utilitarian is also the most intimate and highly prized object of her affections: the wheel's great utility may have made it dear to the Old Wife, but it appears she only appreciates it fully when it no longer becomes a means to an end. Oddly, the wheel would appear to approximate a work of art now it no longer is an object of use, and it is its virtualization as a verbal construct that ensures its transcendence of both cottage and factory.

David Herbison (1800-1880) has been described as 'one of the last, and certainly the most prolific of a group of rural weaver-poets of the nineteenth century'. ${ }^{20}$ Initially a weaver of linen on a handloom on his father's farm, he would later become a representative for a Belfastbased firm of linen-merchants. Kathleen Curtis Wilson's description of the handloom weavers'

\footnotetext{
${ }^{20}$ Ivan Herbison, 'Introduction', in David Herbison, Webs of Fancy: Poems of David Herbison, the Bard of Dunclug, ed. Ivan Herbison (Oxford and Ballymena: The Dunclug Press, 1980), 4.
} 
plight in the early stages of the nineteenth century is relevant to the financial climate within which he was operating:

The handweavers' days of glory and prestigious social status had passed. Handloom weavers' accounts in the 1830 s describe their craft as having been ruined over the previous two decades and present themselves as having been reduced from respectability to destitution. In reality, linen fabric continued to be handwoven for at least another two decades, but on a much reduced scale. ${ }^{21}$

This contextualization of the handloom weaver of this time period - as marginalized and impoverished by mechanization, but nonetheless steadfastly hanging on - is relevant to Herbison's 'To a Mouse, that had Cut a Portion of the Author's Web'. ${ }^{22}$ While the two poems addressed earlier in this article present different responses to the process of modernization that gradually would render the handloom industry obsolete, Herbison's more playful poem is less overtly engaged in the forward march of progress. In terms of genre, the latter is a markedly conservative effort, pitching itself close in both theme and idiom to Robert Burns' 'To a Mouse'. Burns' poem, subtitled 'On Turning up in Her Nest with the Plough, November, 1785', expresses a Romantic solidarity between living creatures. Its speaker not only shows a protective instinct towards the defenseless creature, but also laments fortune's haphazard dealings with 'The best laid schemes o' Mice an' Men'. ${ }^{23}$

Herbison's poem shares with its predecessor the use of the Standard Habbie form and the prosopopeia addressed to a mouse. Both poems also feature a lament of destructiveness, but this is also the regard in which they most manifestly part ways. For while Burns' speaker deplores the damage done to his mouse's nest - 'Thy wee-bit housie, too, in ruin!' 24 Herbison's directs a humorously overblown and belligerent invective at another mouse's little acts of destruction. Taking the form of a curse poem, the latter also signals its belonging within a traditional genre that stretches all the way back to antiquity. This contributes to the sense of a playful, almost arch, deployment of convention: although other Rhyming Weavers also wrote poems modelled upon Burns' 'To a Mouse' - Sarah Leech's 'On the Killing of a Mouse in Harvest' and James Orr's 'To a Sparrow' belong to this category - there is something particularly self-conscious about Herbison's dealings with tradition. This is a poem about theft - about making illegitimate use of others' property - and as such the poem's own excursion into other poets' established territory gains an extra resonance.

Although he would work as an agent for a Belfast linen firm towards the end of his life, Herbison - or the bard of Dunclug, as he was dubbed - was very much identified with his local patch. The mouse of his poem should have stayed at home, but by leaving its own domestic space it also transgresses the speaker's habitus: 'You left behind your cozy nest, / To cut and double, / Amang the yarn that I had dressed / Wi' care and trouble' (II. 39-42). In the first of the poem's thirteen stanzas we are told that the rascally rodent 'never fail[s] to range the house / Frae wa' to wa" (II. 3-4), and the poem opens up a microcosm within the speaker's home, which includes a pantry, the speaker's stacked books, the hearth, and the dark corners where the little creature hides away. Within this terrain, the speaker has hunted the mouse

\footnotetext{
${ }^{21}$ Kathleen Curtis Wilson, Irish People, Irish Linen (Athens: Ohio University Press, 2011), 197.

${ }^{22}$ The poem is printed in David Herbison, Webs of Fancy: Poems of David Herbison, the Bard of Dunclug, ed. Ivan Herbison (Oxford and Ballymena: The Dunclug Press, 1980), 31-32.

${ }^{23}$ Robert Burns, Poems Selected by Don Paterson (London: Faber and Faber, 2001), 43.

${ }^{24}$ Burns, 42.
} 
'frae room to room' (I. 17). This formulation not only echoes the creature's previous unmonitored, destructive passage 'Fra wa' to wa" (I. 4), but also strangely echoes how Christy Blair's children were wont to 'scamper wi' the houn's frae hill to hill' ('The Penitent,' I. 24). One might also catch a hint of the 'rooms' of the stanzas, through which the hunt is industriously rehearsed and repeated as a verbal performance. The speaker has lost control over this domestic space, and the poem is about his plans to police and regain dominion over it. He concentrates his power on the intersection of 'twa bit threads that's set for you' - this being the trap that, he hopes, will end the nuisance of the mouse's stealthy incursions into his space.

The threads of the trap provide an ironic repetition of other threads that the mouse already has cut. Already in the second stanza we are told of how the speaker's 'good wab' has been 'cut' by the intruder (I. 9). For the speaker, the threat to his webs is the reason for his song: without any damage being done to the weaving, there would be no reason for the curse of the poem. If there is a use for the poem, it is because the textile has been reduced - in a formulation that brings Beggs' spinning wheel to mind - to a 'Vile useless thing' (I. 48). On the other hand, though, both the trap and the song rehearse and re-perform the destructive cutting. Herbison makes sure that his readers will not overlook this self-reflective dimension of his poem, by contriving that the mouse's destruction of the web is given a literary echo:

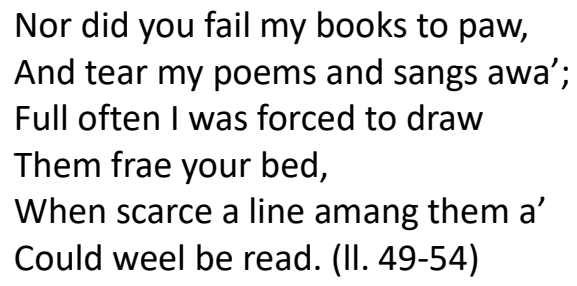

Lines of verse thus double the threads of the weaver's web. Doubling or repetition is also at the heart of Herbison's ludic deployment of the rhyme structure of the Standard Habbie stanza. Three of the last four stanzas play around with the same rhyme, making conspicuous Herbison's fascination with iterative structures. Just to rub it in, the word most consistently deployed in these rhymes is 'again'. In stanza ten, 'again' rhymes with 'hearth-stane', 'taen' and 'strain'. The 'ain' rhyme is subsequently carried into the final rhymes of stanzas eleven and thirteen. First we have 'again' and 'strain', and then - in the poem's conclusion, proleptically anticipating the speaker's regaining unchecked dominion over his domestic space - 'again' and 'ta'en' once more: 'I'll sing again / Through a' the house, the joyfu' blast, / Death has you ta'en' (II. 76-78). Apart from highlighting its own iterative structure, this repeated rhyme highlights the link between poem ('strain') and capture ('ta'en'). The poem itself, one might say, is a kind of trap of words which works to facilitate, through verbal mastery, the speaker's capture of space.

In the rhyme-word 'hearth-stane' - and indeed in the associative forcefield of the other rhymes - one might glimpse the subterranean presence of the word 'stain'. Here one might think of the potential signature-like mark left behind by the marauding mouse on the web, but also of the unnerving blot left by the dead corpse of the little animal after 'Death has you ta'en'. One might also consider the possibility of a moral 'stain'. The speaker is, after all, constructing a very belligerent poem on the basis of another one - Burns' 'To a Mouse' - which celebrated 'Nature's social union' between humans and animals. Herbison's poem also deploys, like the other Weaver poems we have looked at, a religiously inflected discourse. The mouse's 'evil tricks' (I. 43) are denounced, and the description of his behaviour has a moralistic 
tinge: 'you may revel, rant, and reel' (I. 69), the speaker declares, when imagining the animal's enjoyment of his spoils.

The three readings of Weaver poetry that have been offered here have all encountered such instances of religious discourse, as well as spatial articulations and narratives of breakdown. The latter has been given special attention. In one poem the loom is neglected, in another a spinning wheel is rendered obsolete, while in the third the web is sundered by a marauding stranger: in all three cases, these moments of desolation or loss are transformed into the source of a new finding of voice. In Orr's poem it is the 'mair profitable voice' of a modern, entrepreneurial rationality, which no longer is fixed to one place. For Beggs, the cynical development of modern technology may render the spinning wheel a 'useless thing', but it also inspires the Old Wife to an intimate farewell that lovingly dwells upon what has been lost - and invests the 'useless' spinning wheel with a mysterious value of its own. Finally, in Herbison, the abused mouse severs the weaver's painstakingly constructed web, only for the weaver to reconstruct it - and a trap that will do away with the intruder - with intensified gusto. As in Orr's poem, the rebounding victory of Herbison's speaker also attains a calculating mastery of space. These poems provide a perspective on the Rhyming Weaver at variance with Hewitt's vision of a time 'when spinning wheel and loom were at their prime / and every townland earned its name in song. ${ }^{25}$ What they offer instead is a poetry of industry, both fearful and giddy in the company of new engines.

${ }^{25}$ Lines 13-14 of 'Dedication of "The Rhyming Weavers"', in Hewitt, vi. 


\section{Works Cited}

Baraniuk, Carol. James Orr, Poet and Irish Radical. London: Pickering \& Chatto, 2014.

Benjamin, Walter. Illuminations. Ed. Hannah Arendt, trans. Harry Zohn. New York: Schocken Books, 1968.

Burns, Robert. Poems Selected by Don Paterson. London: Faber and Faber, 2001.

Crawford, W. H. The Handloom Weavers and the Ulster Linen Industry. Belfast: Ulster Historical Foundation, 1994.

Gray, Jane. 'Folk Poetry and Working Class Identity in Ulster: An Analysis of James Orr's "The Penitent"'. Journal of Historical Sociology 6.3 (September 1993): 249-275.

Hartman, Geoffrey J. Wordsworth's Poetry, 1787-1814. New Haven: Yale University Press, 1971.

Heaney, Seamus. Finders Keepers: Selected Prose, 1971-2001. London: Faber and Faber, 2002.

Herbison, David. Webs of Fancy: Poems of David Herbison, the Bard of Dunclug. Ed. Ivan Herbison. Oxford and Ballymena: The Dunclug Press, 1980.

Herbison, Ivan. 'Introduction', in David Herbison, Webs of Fancy: Poems of David Herbison, the Bard of Dunclug. Ed. Ivan Herbison. Oxford and Ballymena: The Dunclug Press, 1980.

Herbison, Ivan. 'Beyond the Rhyming Weavers'. Études irlandaises 38.2 (2013): 41-54.

Hewitt, John, ed. Rhyming Weavers \& Other Country Poets of Antrim and Down. Belfast: The Blackstaff Press, 2004 (1974).

Liu, Alan. Wordsworth: The Sense of History. Stanford: Stanford University Press, 1989.

Luckhurst, Roger. The Trauma Question. Manchester: Routledge, 2008.

Malmqvist, Jenny. Belfast Textiles: On Ciaran Carson's Poetics. Linköping: Linköping University, 2013.

Ó Tuathaigh, Gearóid. Ireland Before the Famine, 1798-1848. Dublin: Gill \& Macmillan, 2007 (1972).

Orr, James. Poems on Various Subjects. Belfast: Smyth \& Lyons, 1804.

Paulin, Tom. 'Foreword'. Rhyming Weavers \& Other Country Poets of Antrim and Down. Ed. John Hewitt. Belfast: The Blackstaff Press, 2004 (1974).

Wilson, Kathleen Curtis. Irish People, Irish Linen. Athens: Ohio University Press, 2011. 